\title{
JIHAD VERSI SISWA
}

\section{JIHAD ACCORDING TO STUDENT}

\author{
Abd. Kadir Ahmad \\ Balai Penelitian dan Pengembangan Agama Makassar \\ Jl. AP. Pettarani No. 72 Makassar \\ Email: kadirahmad56@yahoo.co.id
}

Naskah diterima tanggal 29 Agustus 2016. Naskah direvisi tanggal 3 Oktober 2016. Naskah disetujui tanggal 9 November 2016

\begin{abstract}
Abstrak
Kontroversi pemaknaan jihad yang diakibatkan oleh pernyataan-pernyataan dan bahkan perilaku sebagian orang Islam telah menjadikan konsep jihad semakin membingungkan dan simpang siur, terutama pada era modern sekarang ini. Akibatnya pemahaman jihad menjadi warisan bagi generasi pelajar atau siswa di sekolah. Penelitian ini bertujuan memahami bagaimana siswa mengonstruksi pemahaman tentang jihad termasuk pandangan mereka terhadap tindak kekerasan atas nama agama. Penelitian ini dilakukan di Ternate dan Makassar. Kedua daerah ini memiliki sejarah kekerasan bernuansa agama. Makassar dengan kasus peledakan bom terhadap sasaran yang dikaitkan dengan simbol kapitalisme global (khususnya AS) dan Ternate dengan sejarah konflik sosial. Hasil penelitian bagian terbesar ( 63 persen) pemahaman siswa mengenai jihad bersifat puritanisme (fundamentalis sampai ekstrim). Sementara hanya (18 persen) yang dapat dimaknai sebagai moderat (inklusif). Untuk kedua komunitas, kecenderungan puritanisme lebih kuat di kalangan siswa Ternate (70 persen) dan pandangan moderat hanya (13 persen). Sementara siswa di Makassar, meski tetap didominasi pemaknaan puritanisme (52 persen), kecenderungan pandangan moderat tidak terlalu rendah (27 persen). Pemaknaan siswa tentang jihad pada daerah kasus didominasi oleh paham yang sempit dan lebih mengarah kepada pengertian qital. Hal itu dipahami dari penggunanaan istilah makna jihad sebagai perjuangan, pengorbanan, perang, mati syahid dan pembelaan agama (Islam). Hal ini berbeda dengan prinsip jihad sebagaimana dipahami dari Alquran dan tradisi Nabi. Tidak ada korelasi yang signifikan antara pemahaman jihad dengan sumber-sumber belajar siswa, termasuk sekolah. Hal ini dapat dipahami sebagai lemahnya peran sekolah dalam memberi pemahaman tentang ajaran Islam yang amat sentral tersebut. Pemahaman tentang jihad lebih ditentukan oleh konstruksi sosial.
\end{abstract}

Kata Kunci: jihad, siswa, inklusif, fundamental, puritanisme.

\begin{abstract}
Controversy about the meaning of jihad caused by statements and even the behavior of some Muslims have made the concept of jihad more confused, especially in the modern era. As a implication, understanding of jihad into a legacy for generations of students or students at school. This research aims to describe how students construct an paradigm of jihad including their views against violence in the name of religion. This research was conducted in Ternate and Makassar. Both of these areas have a history of religious violence. Makassar with cases of bombings against targets associated with the symbols of global capitalism (especially the USA) and Ternate with a history of social conflict. The results of the study the largest respon rate (63 percent) students' understanding of jihad is puritanism (fundamentalists to the extreme). While only 18 percent of which can be defined as moderate (inclusive). For both communities, puritanism stronger tendency among students Ternate (70 percent) and only 13 percent moderate views. While students in Makassar, though still dominated the meaning of Puritanism (52 percent), the trend of moderate views (27 percent). Making of students on jihad in case the area is dominated by a narrow understanding and understanding leads to qital. It was understood from the term meaning of jihad as a struggle, sacrifice, war, martyrdom and defense of religion (Islam). This is in contrast with the principle of jihad as understood from the Qur'an and the traditions of the Prophet. There is no significant correlation between the understanding of jihad with the sources of student learning, including school. This can be understood as a weak role of schools in providing an understanding of the teachings of Islam which is very central for them. Understanding of jihad be determined by the social construction.
\end{abstract}

Keywords: jihad, student, inclusif, fundamental, furitanism. 


\section{PENDAHULUAN}

$\mathrm{T}$ idak ada satu aspek dari agama Islam yang akhir-akhir ini mendapat porsi besar di mata publik dan berbagai media selain jihad. Hal itu, antara lain, disebabkan oleh berkembangnya klaim yang menyemangati berbagai aksi teror yang melibatkan person-person orang Islam, atas landasan jihad. Padahal sesungguhnya, menurut El-Fadl, jihad dalam Islam merupakan fondasi berbagai kemampuan Islam untuk hidup berdampingan secara damai dan bekerjasama dengan non-muslim. Meskipun telah banyak tulisan mengenai topik jihad, apa yang menjadi pertanyaan pokok adalah bagaimana begitu banyak kalangan Islam yang memahaminya secara berbeda. Selain karena pemahaman yang dangkal, kontroversi pemaknaan jihad juga karena pernyataanpernyataan dan bahkan kelakuan sebagian orang Islam telah menjadikan konsep jihad semakin membingungkan dan simpang siur, terutama pada era modern sekarang ini. Seperti diakui El Fadl, jihad, sebagaimana banyak dilansir media Barat dan yang telah dieksploitasi kelompok ekstrim, sering dikaitkan dengan ide tentang perang suci, yang dikobarkan atas nama Tuhan, terhadap orang kafir dan kerap disamakan dengan sikap tidak toleran dalam beragama di atas segalanya, isu terorisme telah mencemarkan reputasi agama terbesar kedua di dunia tersebut (El Fadl, 2007: 220).

Isu yang berkembang sekitar pemaknaan jihad dan implikasinya dalam kehidupan telah membedakan posisi kelompok moderat dan puritan di kalangan umat Islam, seakan dua dunia berbeda. Masalahnya terletak pada kenyataan bahwa kalangan puritan berbicara lebih keras daripada kalangan moderat. Puritan tidak mengharamkan berbicara dengan senjata, sementara senjata apa yang dimiliki kolompok moderat untuk berbicara?

Jika pemaknaan terhadap jihad telah sampai pada pembelahan antara kelompok moderat dan puritan dalam masyarakat, maka dimanakah posisi segmen masyarakat yang sedang belajar di bangku sekolah? Bagaimanakah mereka memberikan makna terhadap jihad? Hal ini penting dipertanyakan, sebab secara politis, pendidikan agama di sekolah di Indonesia, mendapat legitimasi cukup kuat dalam sistem pendidikan nasional. Pendidikan agama adalah upaya sadar dan terencana dalam menyiapkan peserta didik untuk mengenal, memahami, menghayati hingga mengimani, bertakwa, dan berakhlak mulia dalam mengamalkan ajaran agama
Islam dari sumber utamanya kitab suci Alquran dan hadis, melalui kegiatan bimbingan, pengajaran, latihan, serta penggunaan pengalaman. Dibarengi tuntutan untuk menghormati penganut agama lain dalam masyarakat hingga terwujudnya kesatuan dan persatuan bangsa (Depdiknas, 2003: 7). Sedangkan Langgulung (2003:16) pendidikan dimaknai sebagai salah satu bentuk interaksi manusia melalui suatu jaringan hubungan kemanusiaan.

Secara sosiologis siswa sekolah merupakan generasi yang dalam perkembangannya tidak terlepas dari sosialisasi nilai dan cara hidup dari mereka yang lebih tua di dalam masyarakat. Dalam konteks ini, pemaknaan jihad dan implikasinya dalam interaksi sosial merupakan satu di antara konsep-konsep yang diduga telah membentuk pola pikir siswa. Penelitian tentang pemaknaan jihad di kalangan siswa, mendapat legitimasi dari cara pandang seperti ini. Penelitian ini dikemas dalam satu paket penelitian bertajuk Pola Keberagamaan Siswa, membuat substansinya lebih luas dari sekadar pertanyaan tentang jihad. Untuk kepentingan tulisan ini, penulis hanya mengangkat tema jihad, sesuatu yang cukup relevan dengan kondisi terakhir di negeri ini, bersamaan dengan semakin menajamnya polarisasi pemaknaan tersebut, terutama menyusul eksekusi mati Amrozi dan kawan-kawan di depan regu tembak, yang dieksekusi mati pada Minggu, 9 November 2008, pukul 00.15 di Nusakambangan, meski penelitian itu sendiri sudah dilakukan jauh hari sebelumnya, yakni Bulan Agustus 2008.

Ketua Majelis Ulama Indonesia KH. Ma’ruf Amin, misalnya, menegaskan bahwa Amrozi, Imam Samudra, dan Ali Gufron alias Mukhlas bukan mati syahid. Menurutnya, perjuangan Amrozi CS dengan teror bukan cara yang tepat dalam perjuangan Islam. Perjuangan dalam Islam pada masa damai dilakukan dengan dakwah. Kecuali di daerah perang. Indonesia (saat peristiwa bom Bali dan sekarang) tidak sedang dalam perang (Tempo, 10/11/2008). Sebelum dieksekusi, Imam Samudra menulis surat wasiat untuk dibacakan kepada publik. Isinya, antara lain, menyebutkan gelar teroris lebih mulia daripada ulama yang tidak peduli pada saudara yang dibunuh orang kafir. Para ulama menilai itu tidak tepat, ujar Ma'ruf Amin, seperti ditulis Tempo. Pendapat senada diutarakan Ketua Umum Pengurus Besar Nahdlatul Wathan Tuan Guru Bajang KH. Muhammad Zainul Madjdi. Menurut dia, mujahid adalah orang yang memiliki dedikasi tinggi dan penuh tanggung jawab pada masyarakat. Termasuk jauh dari pikiran ekstrimitas. Menurutnya, cara 
Amrozi CS melawan Amerika Serikat tidaklah tepat. Seharusnya protes terhadap AS dilakukan di negeri adidaya itu, bukan di Indonesia. Perjuangan yang benar bukan menggunakan senjata dan tidak boleh menyakiti. Islam, katanya, tidak pernah ada masalah dengan kemajemukan di kalangan masyarakat.

Hal ini berbeda dengan pendapat Abu Bakar Ba'asyir. Di Lamongan, sebelum jenazah Amrozi diberangkatkan ke pemakaman, mantan pimpinan Majelis Mujahidin Indonesia itu, mengaku sangat bangga pada Amrozi, Muklas, dan Imam Samudra yang dia anggap mati syahid. Konsep mati syahid secara teologis dipahami sebagai status yang pantas diterima oleh seseorang yang meninggal karena berjihad di jalan Allah atau mujahid. Masalah pokok penelitian ini adalah bagaimana pemaknaan yang diberikan oleh siswa mengenai jihad? Apakah pemaknaan jihad tersebut terkait dengan pemahaman tentang kekerasan atas nama agama? Dengan demikian, penelitian ini bertujuan memahami bagaimana siswa mengonstruksi pemahaman tentang jihad termasuk pandangan mereka terhadap tindak kekerasan atas nama agama.

\section{METODE PENELITIAN}

Penelitian ini dilakukan di Ternate dan Makassar. Kedua daerah ini memiliki sejarah kekerasan bernuansa agama. Makassar dengan kasus peledakan bom terhadap sasaran yang dikaitkan dengan simbol kapitalisme global (khususnya AS) dan Ternate dengan sejarah konflik berdarah. Penelitian ini memilih sampel pada lima Sekolah Menengah Atas Negeri di Ternate dan Makassar yang diklasifikasikan ke dalam sekolah unggulan, sekolah favorit dan sekolah biasa. Berdasar kriteria tersebut, terpilih 3 sekolah SMA Negeri di Ternate dan 2 sekolah setingkat di Makassar. Jumlah siswa yang terjaring sebagai sampel adalah 121 siswa di Ternate dan 91 siswa di Makassar.

Siswa-siswa yang menjadi responden memiliki latar belakang pekerjaan orang tua pegawai negeri sipil (PNS) 41 persen, pekerjaan swasta 31 persen, dan 14 persen lainnya petani. Sedangkan latar belakang pendidikan orang tua siswa adalah tamat SD 7 persen, tamat SMP 12 persen, tamat SMA 41 persen, S1 25 persen, dan S2/S3 5 persen. Analisis data dilakukan dengan menggunakan frekuensi dan korelasi Spearman untuk melihat adanya hubungan antara satu variabel dengan variabel lain.

\section{PEMBAHASAN}

\section{Konstruksi Jihad}

Pandangan siswa tentang jihad didekati dengan menggunakan pendekatan semiotik yang memberikan tempat sentral pada tanda. Sebagai ilmu yang mengkaji tanda, semiotik juga melihat tanda sebagai gejala budaya. Semiotik melihat kebudayaan sebagai suatu sistem pemaknaan. Bahkan makna tanda adalah hasil suatu konvensi, suatu prinsip dalam kehidupan berkebudayaan. Kalaupun yang diteliti itu suatu teks atau ungkapan bahasa, maka iapun dilihat sebagai tanda (Benny Hoed, 2008: 89) .

Dengan menggunakan bahasa sebagai tanda dari apa yang diinginkan atau dimaksudkan, ternyata siswa kebanyakan merepresentasikan makna jihad lewat konsep berperang, berjuang, membela, berkorban sampai kepada yang paling netral, berusaha. Konsep berperang menempati tingkat paling tinggi dari hirarki ekstrimitas yang diwakilkan oleh pemaknaan jihad.

Sebagian ulama menggariskan lima jenis jihad berdasarkan Alquran dan Sunnah yaitu jihad dengan ucapan, jihad dengan pendidikan, jihad dengan kuasa pemerintahan, jihad dengan politik, jihad dengan harta benda (Irawan, 2014: 67, lihat pula (Nst, 2013: 146). Berbeda dengan Nahrawi (2009: 64-69) sebagai perang, haji mabrur, menyampaikan kebenaran kepada penguasa yang dzalim, berbakti kepada orang tua, menuntut ilmu dan mengembangkan pendidikan, dan membantu fakirmiskin. Konsep jihad ini kadang diimplementasikan oleh para tokoh tertentu untuk menggalang umat dalam rangka mendirikan Negara Islam di tengahtengah bangunan Negara Kesatuan Republik Indonesia yang diakui keabsahannya oleh sebagian besar umat Islam. Maka konflik pun berkembang dan diwariskan pada anak-anak muda kebanyakan yang tidak mengerti Islam yang sebenarnya.

Namun pengertian berjuang di jalan Allah berbeda dengan pengertian terorisme yang sering dijumpai yang digunakan pada suatu permusuhan yang ditekuni oleh individu, kelompok, maupun negara dengan penuh kesewenangan terhadap manusia baik di bidang agama, darah, akal, harta, maupun kehormatan (Nur, 2010: 32-33). Pemaknaan dengan berjuang menempati urutan tertinggi dengan redaksi yang bervariasi tetap dengan makna relatif sama. Selanjutnya akan dipaparkan pemaknaan yang diberikan siswa dengan menggunakan konsep berjuang.

\section{Jihad sebagai Perjuangan}

Di bawah ini ditampilkan konstruksi jihad bagi siswa yang terkait dengan konsep jihad sebagai sebuah perjuangan. Hal ini terutama 
dengan penggunaan bahasa atau kata "berjuang" sebagai tanda. Berikut adalah konstruksi makna jihad, kaitannya dengan pemaknaan Jihad sebagai perjuangan:

1. Berjuang untuk mempertahankan kebenaran di jalan Allah dan membela agama;

2. Berjuang di jalan Allah dan rela berkorban;

3. Berjuang dengan bersungguh-sungguh terhadap apa yang benar sesuai syariat Islam;

4. Berjuang membela agama diajarkan Allah agar mendapat ridha Allah;

5. Berjuang di jalan Allah membela agama;

6. Berjuang di jalan yang benar, yaitu di jalan Allah;

7. Berjuang mempertahankan agama Islam;

8. Berjuang membela agama;

9. Berjuang menegakkan agama Allah walaupun nyawa sebagai taruhan;

10. Berjuang menegakkan agama Allah;

11. Berjuang di jalan yang benar dalam bentuk apa pun juga yang penting kita;

12. Melakukannya dengan ikhlas semata mata karena Allah;

13. Berjuang demi agama Islam di jalan Allah dengan niat ikhlas hanya untuk mempertahankan agamanya;

14. Berjuang, membela agama Allah (Islam) sampai titik darah penghabisan;

15. Berjuang di medan perang untuk membela agama Allah dan semata-mata hanya untuk Allah;

16. Berjuang di jalan Allah, atau membela agama Allah swt, jangan peduli nasib dirinya;

17. Perjuangan (perang suci) untuk membela agama di jalan Allah;

18. Memperjuangkan Islam dan rela mati untuk diperjuangkan;

19. Berjuang menegakkan kalimat Allah;

20. Memperjuangkan agama Allah tanpa pamrih dan mengharap rida Allah;

21. Memperjuangkan nama Allah di jalan-Nya;

22. Berjuang di jalan Allah;

23. Berjuang mempertahankan agama Allah;

24. Memperjuangkan kalimat Allah;

25. Memperjuangkan ajaran agama Islam;

26. Memperjuangkan agama Allah dijalan yang diredhai Allah;

27. Memperjuangkan ajaran dan agama Islam semata-mata karena ingin mendapat rida Allah;

28. Berjuang di jalan Allah atau membela agama Allah (Islam ) dari kaum Yahudi
Berjuang, memperjuangkan, dan perjuangan menjadi kata kunci yang pada umumnya mengontruksi ide siswa tentang jihad. Hal ini mendapatkan kesan kuat seakan tidak ada medan jihad tanpa perjuangan. Perjuangan yang dimaksud bervariasi ber poros pada berjuang: di jalan Allah, agama Islam, agama, ajaran Islam, kalimat Allah, agama Allah, Islam, sampai kepada yang lebih umum berjuang di jalan yang benar. Berjuang itu sendiri pada dasarnya berarti berlaga, berlawan, memperebutkan sesuatu dengan mengadu tenaga, berperang, berkelahi, dan berusaha sekuat tenaga tentang sesuatu, berusaha penuh dengan kesukaran dan bahaya (Depdiknas, 2002: 478).

Makna jihad dengan representasi tanda berjuang, memperjuangkan, atau perjuangan, dengan demikian, bergerak antara keharusan berperang di jalan Allah dan berusaha sekuat tenaga untuk mencapai sesuatu di jalan Allah. Namun demikian, dalam konteks konstruksi siswa mengenai hal ini, kecenderungan ke arah makna yang pertama lebih kuat. Selain dapat terlihat dari pengungkapan kalimat-kalimat dalam tabel, juga akan tampak jelas pada penguatan makna tersebut dengan konstruksi makna jihad lewat tanda (kata) berperang. Dalam tabel terlihat perjuangan paling ekstrim adalah berjuang sampai titik darah penghabisan, tanpa mempedulikan nasib sendiri, walaupun nyawa sebagai taruhan, rela mati. Sementara perjuangan yang lebih luas adalah memperjuangkan agama Allah di jalan yang diridhai Allah, tanpa pamrih, dan niat ikhlas. Berjuang melawan siapa, tidak disebutkan secara spesifik, kecuali ada siswa yang menyebut Yahudi. Dengan demikian pemaknaannya bisa siapa atau kelompok apa saja.

\section{Jihad sebagai Perang}

Siswa memaknai jihad dengan berperang lebih menspesifikkan makna berjuang daripada maknanya yang lain. Hal ini diungkapkan melalui frasa: melakukan perang, memerangi, perang suci, berperang. Dalam Kamus Besar Bahasa Indonesia berperang diartikan permusuhan antara dua negara (bangsa, agama, suku, dsb.); pertempuran besar bersenjata antara dua pasukan atau lebih; perkelahian; cara mengungkapkan permusuhan. Siswa juga mengungkapkan makna jihad dengan tanda perang dalam konstruksi kalimat beragam. Berikut adalah konstruksi makna jihad kaitannya dengan pemaknaan jihad sebagai perang: 
1. Melakukan perang untuk membela agama Islam dengan hati ikhlas

1. Mengarahkan segala kemampuan dan tenaga
untuk memerangi orang-orang kafir dengan
tujuan mengharapkan ridha Allah swt dan me-
ninggikan kalimatnya

2. Perang suci memerangi orang kafir unruk membela agama Islam

3. Berjihad di jalan Allah yaitu untuk membela/ berperang demi membela agama Islam biar nyawa taruhannya mereka tetap membela agama mereka sendiri

4. Berperang di jalan untuk membela agama Islam

5. Berperang di jalan Allah dan apabila orang tersebut mati, orang tersebut disebut mati syahid

6. Memerangi suatu kaum yang zalim, berjuang menegakkan agama Islam dalam segala hal

7. Berperang untuk membela agama Allah dan semata hanya untuk Allah

8. Perang suci memerangi orang kafir untuk membela agama Islam dan perang di jalan Allah swt

9. Berperang di jalan Allah demi membela agama Islam

10. Perang suci memerangi orang kafir untuk membela agama Islam dan perang di jalan Allah swt

11. Mengorbankan jiwa dan raga, memerangi orang kafir, untuk membela agama Allah, yakni Islam

12. Perang di jalan Allah

13. Perang suci memerangi orang kafir untuk membela agama Islam

14. Melakukan perjalanan atau pertempuran semata-mata untuk Allah

15. Berperang membela Islam bertujuan membuat perdamian

16. Menegakkan syariat Islam dan melawan orang yang menghancurkan Islam

Berbeda dengan berjuang yang konteksnya dapat berupa perang dan dapat pula berarti usaha sekuat tenaga untuk mencapai sesuatu dalam suatu kondisi penuh resiko, maka perang jelas bermakna perlawanan dan konfrontasi terhadap pihak lain. Bahkan dalam pernyataan siswa berupa pertempuran. Dengan siapa perang harus dilakukan? Tanda-tanda tersebut menyebutkan secara umum perang diarahkan kepada siapa saja yang ingin menghancurkan Islam dan kaum zalim. Kalau ini yang terjadi, maka konteksnya bisa orang Islam itu sendiri yang oleh kelompok yang berkepentingan dipandang akan menghancurkan Islam atau kelompok lain di luar Islam, orang kafir. Dalam realitas komunitas Islam berhaluan keras, perang bisa saja diarahkan pada sesama pemeluk agama yang dianggap sesat. Konsekuensi berperang di jalan Allah diganjar dengan mati syahid, kalau yang bersangkutan gugur di dalam aksi tersebut.

\section{Jihad sebagai Pengorbanan}

Konsekuensi dari perjuangan dan bahkan perang ditandai dengan pengorbanan. Siswa memaknai jihad, dengan demikian, dengan keharusan berkorban atau pengorbanan. Kata yang digunakan sebagai tanda adalah berkorban, mengorbankan, dalam konteks rumusan kalimat yang bervariasi. Berikut adalah konstruksi makna jihad oleh siswa, kaitannya dengan pemaknaan jihad sebagai pengorbanan:

1. Mengorbankan nyawa seseorang demi kepentingan di jalan Allah

2. Rela berkorban demi membela apa saja, walaupun harus mati atau hidup, yang penting di jalan yang benar (di jalan Allah)

3. Mengorbankan jiwa dan raga, memerangi orang kafir, untuk membela agama Allah, yakni Islam

4. Rela berkorban di jalan Allah

5. Mengorbankan segala sesuatu untuk Allah, membela kebaikan

6. Rela mengorbankan harta, keluarga, bahkan jiwa sekaligus untuk mempertahankan dan membela agama Allah.

Materi pengorbanan dapat berupa nyawa atau jiwa dan raga, serta harta, atau segala sesuatu (yang bernilai), termasuk keluarga. Sama dengan berjuang dan berperang, medannya adalah jalan Allah. Konteks ini mengandung pemahaman bahwa sesungguhnya perjuangan dan perang membutuhkan pengorbanan, dan bahwa pengorbanan itu sendiri merupakan sebuah jihad.

\section{Jihad sebagai Mati Syahid}

Sebagian siswa memahami jihad sebagai mati (syahid) itu sendiri, atau mati di dalam membela agama Allah. Dengan demikian, taruhan jihad adalah mati. Hal itu dapat dilihat pada 
statemen berikut sebagai konstruksi makna jihad oleh siswa, kaitannya dengan pemaknaan Jihad sebagai Mati Syahid

\begin{tabular}{|ll|}
\hline 1. & Mati dalam membela agama Allah \\
\hline $\begin{array}{l}\text { 2. } \\
\text { Wafat membela agama, tanah air, bangsa, ser- } \\
\text { ta keluarga, di jalan Allah }\end{array}$ \\
\hline 3. & Meninggal karena membela kebenaran \\
\hline $\begin{array}{l}\text { 4. } \\
\text { Seorang yang wafat demi membela ajaran Al- } \\
\text { lah swt }\end{array}$ \\
\hline
\end{tabular}

Mati, wafat, meninggal, memiliki makna yang sama. Pemaknaan jihad sebagai mati terkait bukan saja dengan mati di jalan Allah tetapi dalam membela tanah air dan keluarga dan membela kebenaran.

\section{Jihad Sebagai Pembelaan Agama}

Kebanyakan konsep berjuang, berperang, dan berkorban di jalan Allah dikaitkan dengan tujuan membela agama Allah. Jadi bersifat defensif. Hanya sebagai kecil yang bermakna agresif dalam berjuang dan berperang sekalipun. Itulah sebabnya, trend penting pemaknaan jihad adalah membela Islam itu sendiri dengan berbagai kata semacamnya sebagai tanda. Selain membela juga mempertahankan, dua konsep yang digunakan untuk membangun mekanisme pertahanan diri (self defense mechanism) kaum muslimin menurut versi siswa. Berikut ini adalah bentuk pemaknaan jihad dengan pembelaan Islam oleh siswa:

\begin{tabular}{|l|l|}
\hline 1. & $\begin{array}{l}\text { Membela agama Islam sampai titik darah } \\
\text { penghabisan }\end{array}$ \\
\hline 2. & Membela kebenaran di jalan Allah \\
\hline
\end{tabular}

3. Membela kebenaran di jalan Allah dengan mengorbankan harta dan jiwa

4. Membela kebenaran di jalan Allah, menjalankan peraturan Allah

5. Melakukan pembelaan terhadap agama yang ia yakini saat ini, tanpa suatu kekerasan sesama pemeluk agama lain dan sesuai ridho Allah swt

6. Membela aqidah agama Islam

7. Membela agama dari tindakan agama lain

8. Orang yang memberikan seluruh hidupnya untuk membela Allah

9. Merelakan diri atau mengabdikan diri kepada Allah swt apapun yang terjadi demi membela umat Islam dalam bentuk apapun, sekalipun mempertaruhkan nyawa.
10. Membela Islam sampai titik darah penghabisan

11. Membela kepentingan Islam, tidak hanya dengan berperang, tapi juga dalam menjalankan kehidupan ini.

\section{Membela kebenaran Islam}

13. Membela apa yang benar menurut Islam

Pembelaan agama merupakan tanda paling umum untuk memaknai jihad baik langsung maupun tidak. Tanda yang langsung adalah seperti konstruksi jihad pada tabel 5; sementara tanda yang tidak langsung dapat dilihat pada tujuan dilaksanakannya perjuangan dan perang, dan pengorbanan yaitu dalam rangka membela agama Allah (tabel 1 dan 2, dan 3). Sasaran pembelaan adalah kebenaran Islam, kepentingan Islam, membela umat Islam, membela aqidah, membela Allah. Tingkat pembelaan sampai kepada titik darah penghabisan atau dengan nyawa sebagai taruhannya sampai kepada pembelaan tanpa kekerasan terhadap pemeluk agama lain.

\section{Jihad sebagai Kiprah Umum di Jalan Allah}

Ada sejumlah siswa yang memaknai jihad dengan konsep-konsep yang lebih umum dan inklusif, dengan tanda-tanda: usaha, sesuatu yang dikerjakan, pekerjaan dan sebagainya.

Berikut ini sejumlah konstruksi pemaknaan makna jihad dalam tanda yang lebih umum, kaitannya dengan pemaknaan Jihad secara Inklusif:

1. Usaha mencapai keridhaan Allah

2. Sesuatu yang dikerjakan semata-mata karena Allah.

3. Suatu pekerjaan yang dilakukan demi mendapat keridhaan Allah

4. Menegakkan kebenaran di jalan Allah dengan melaksanakan yang diperintahkan dan menjauhi yang dilarang.

5. Hamba Allah yang senantiasa mengikuti perintah Allah dan menjauhi larangan Allah.

6. Sesuatu yang bila dikerjakan pahalanya akan sangat besar di mata Allah

7. Membawa nama Islam selama benar caranya dan di jalur yang benar

8. Orang yg menegakkan agama Allah

9. Menyebarkan agama Islam sesuai kaidah-kaidah yang ada dalam Alquran 
10. Bersungguh-sungguh melakukan sesuatu, baik perang demi Islam maupun pekerjaan pekerjaan di jalan Allah bahkan mengorbankan harta, benda, jiwa, dan raga.

11. Dalam melakukan perbuatan diawali demgan niat karena Allah

12. Melakukan suatu perbuatan atas nama Allah

13. Melakukan perintah Allah dan selalu beribadah kepadaNya sesuai dengan perintahnya dan menjauhi larangannya. Bukan hanya berperang saja yang dinamakan jihad.

14. Melakukan suatu perbuatan karena Allah

15. Melakukan pekerjaan baik yang mengorbankan nyawa atau pun tidak dijalan Allah.

16. Memerangi diri sendiri agar tidak berbuat sesuatu yang dilarang oleh Allah swt dengan melaksanakan ibadah sebaik-baiknya

17. Melawan hawa nafsu, contoh puasa, atau pun bisa disebut melawan musuh Allah

Tanda-tanda yang mengandung makna jihad diwakili oleh konsep melawan hawa nafsu, memerangi diri sendiri, melakukan pekerjaan, perbuatan, melakukan perintah Allah dan menjauhi larangannya. Selain itu terdapat konsep bersungguhsungguh dalam pekerjaan, menyebarkan Islam, membawakan nama Islam secara benar, usaha yang diridhai Allah.

Meski jumlahnya tidak sebesar yang memaknai jihad dengan cara yang lainnya, pemaknaan yang terakhir ini mewakili makna jihad yang lebih luas dan kontekstual sesuai dengan kondisi dan tantangan umat Islam sekarang ini: kebodohan, kemiskinan, dan keterbelakangan.

Konstruksi pemaknaan tentang jihad dirumuskan dengan kalimat yang berbeda tetapi makna yang relatif sama, dengan merujuk kepada penggunaan konsep tertentu sebagai kata-kata kunci seperti berjuang, berperang, berkorban, mati di jalan Allah, dalam rangka membela agama Islam mendominasi konstruksi pemaknaan siswa tentang jihad. Meski demikian, sejumlah siswa juga dapat memahami dalam pengertiannya yang lebih luas dan inklusif sebagai usaha di jalan Allah.

Deskripsi tentang pemaknaan jihad dengan penggunaan bahasa membawa kepada kategori inklusif untuk pemaknaan jihad sebagai usaha sungguh-sungguh dalam kebaikan; fundamentalis untuk kategori berjuang dan membela, dan ekstrim untuk kategori perang dan mati syahid.
Selanjutnya kategori fundamentalis dan ekstrim lebih disederhanakan dengan konsep puritanisme dan kategori inklusif digolongkan ke pandangan moderat, meminjam tipologi El-Fadl.

Bagian terbesar (63 persen) pemahaman siswa mengenai jihad bersifat puritanisme (fundamentalis sampai ekstrim). Sementara hanya sebagian kecil (18 persen) yang dapat dimaknai sebagai moderat (inklusif). Untuk kedua komunitas, kecenderungan puritanisme lebih kuat di kalangan siswa Ternate (70 persen) dan pandangan moderat hanya (13 persen). Sementara siswa di Makassar, meski tetap didominasi pemaknaan puritanisme (52 persen), kecenderungan pandangan moderat tidak terlalu rendah (27 persen).

Iklim mikro keberagamaan kedua komunitas muslim tersebut boleh jadi berpengaruh pada pandangan warganya: Ternate pernah mengalami suasana konflik bernuansa agama yang mengubah struktur sosial setempat, sementara Makassar menjadi salah satu simpul dinamika keberagamaan puritanisme, tetapi tanpa konflik manifes antar dan intern umat beragama secara masif.

Ada korelasi signifikan antara latar belakang sekolah (unggulan dan biasa) $(\mathrm{P}=0.012>0.05)$ dan latar belakang pendidikan orang tua $(\mathrm{P}=0,019>0,05)$ dengan pamaknaan tentang jihad. Siswa sekolah non-unggulan dan dengan orang tua berpendidikan relatif rendah cenderung lebih puritan.

Meski kecenderungan kuat ke arah puritanisme terjadi, namun sikap tersebut tidak ada hubungan sama sekali dengan penggunaan kekerasan atas nama agama. Bahkan siswa menolak perilaku radikalisme yang memperatasnamakan agama, dengan kualifikasi 18 persen kurang setuju, 34 persen tidak setuju, dan 37 persen sangat tidak setuju. Hanya 9 persen yang setuju kekerasan agama. Ini merupakan titik balik dari pola penyelesaian masalah dengan kekerasan oleh kelompok agama tertentu ke arah kebutuhan hidup secara lebih aman dan damai dan lebih mementingkan pendekatan dakwah secara luas. Terhadap penganut aliran sesat, misalnya, siswa cenderung ke arah penyelesaian melalui jalur pembinaan (75 persen), daripada dengan cara lainnya, termasuk pembubaran.

Selain tidak berkorelasi dengan pandangan tentang kekerasan atas nama agama, pendangan jihad juga tidak berkorelasi dengan referensi siswa belajar agama. Dalam penelitian ini, ditemukan bahwa siswa lebih banyak belajar agama ke guru agama di sekolah (30 persen), orang tua di rumah (21 persen), buku-buku agama (14 persen), belajar 
ke semua sumber tersebut, termasuk senior dalam organisasi dan tv (23 persen).

Meski guru agama banyak dijadikan referensi oleh siswa, materi jihad sendiri tidak termuat dalam sillabus mata ajar agama, sesuatu yang menjadi acuan guru untuk mengajar. Begitu pula halnya dengan buku-buku bacaan, tidak ditemukan yang memuat pembahasan jihad secara konprehensif yang dapat dijadikan pegangan bagi siswa. Referensi buku agama yang dibaca banyak terkait dengan buku tentang berita eskatologis, ibadah, novel islami, tokoh-tokoh dalam sejarah Islam sampai pacaran ala Islami, dan buku provokatif, seperti aliranaliran sesat di Indonesia. Penulis tidak menemukan akses siswa kepada kajian yang lebih mencerahkan mengenai jihad dan tema-tema sosial yang lebih konstruktif untuk pembangunan tatanan kehidupan lebih aman, damai, dan sejahtera. Boleh jadi tingkat ketertarikan dan kebutuhan siswa belum sampai ke sana.

Jika demikian halnya, maka pemaknaan siswa mengenai jihad lebih merupakan hasil konstruksi sosial secara umum. Temuan penting dalam penelitian ini adalah kuatnya arus pemaknaan jihad sebagai perjuangan, pengorbanan, perang, mati syahid dan pembelaan agama. Hanya sebagian kecil siswa yang memberikan makna jihad sebagai sebuah usaha sungguh-sunguh dalam setiap kebaikan dalam medan kehidupan pada umumnya. Pemaknaan seperti itu tidak muncul begitu saja, melainkan terkait dengan konstruksi masyarakat tentang jihad. Secara teoritis hubungan ini dapat dilihat dari perspektif agama dan pembangunan dunia.

Menurut Berger, setiap masyarakat manusia adalah suatu usaha pembangunan dunia. Agama menempati suatu tempat tersendiri dalam usaha ini. Masyarakat adalah fenomena dialektik dalam pengertian bahwa masyarakat adalah suatu produk manusia yang akan selalu memberi tindak kepada produsernya. Proses dialektik fundamental dari masyarakat terdiri dari tiga momentum, atau langkah, yaitu eksternalisasi, obyektivasi, dan internalisasi. Eksternalisasi adalah suatu pencurahan kedirian manusia secara terus-menerus ke dalam dunia, baik dalam aktivitas fisis maupun mentalnya. Obyektivasi adalah disandangnya produk-produk aktivitas itu (baik fisis maupun mental), suatu realitas yang berhadapan dengan para produsennya semula, dalam bentuk suatu kefaktaan yang eksternal terhadap para produsen itu sendiri. Internalisasi adalah peresapan kembali realitas tersebut oleh manusia dan mentransformasikannya sekali lagi dari struktur-struktur dunia obyektif ke dalam struktur-struktur kesadaran subyektif (Berger, 1994: 5).

Setiap masyarakat yang terus berjalan dalam sejarah akan menghadapi masalah pengalihan makna-makna terobyektivasinya dari satu generasi ke generasi berikutnya. Masalah ini diselesaikan dengan cara sosialisasi, yaitu proses yang dipakai mendidik generasi baru untuk hidup sesuai dengan program-program kelembagaan masyarakat tersebut. Tentu saja sosialisasi secara psikologis dapat disebut sebagai suatu proses belajar. Generasi baru diperkenalkan pada makna-makna budaya, belajar ikut serta dalam tugas-tugas yang sudah ditetapkan dan menerima peran-peran selain menerima identitas-identitas yang membentuk struktur sosialnya. Namun sosialisasi memiliki suatu dimensi penting yang tidak sepenuhnya bisa dijelaskan hanya dengan berbicara mengenai proses belajar. Individu tidak hanya belajar mengenai maknamakna terobyektivasi tetapi juga menghubungkan diri dengan, dan dibentuk oleh, makna-makna tersebut. Dia menyerap makna-makna tersebut dan menjadikannya makna-maknanya sendiri. Dia menjadi tidak saja seorang yang memiliki maknamakna ini, tetapi juga seorang yang mewakili dan mengekspresikan makna-makna tersebut.

Keberhasilan sosialisasi tergantung pada adanya simetri antara dunia obyektif masyarakat dengan dunia subyektif individu. Jika kita membayangkan seorang individu yang tersosialisasi total, maka setiap makna yang secara obyektif terdapat dalam dunia sosial akan mempunyai makna analognya secara subyektif di dalam kesadaran individu itu sendiri. Sosialisasi total seperti itu secara empiris tidak akan ada dan secara teoretis tidak mungkin ada, walaupun barangkali ini hanya akibat dari keragaman biologis individu-individu. Namun terdapat tingkat-tingkat keberhasilan dalam sosialisasi. Sosialisasi yang berhasil akan memberikan suatu simetri obyektif/subyektif tingkat tinggi, sementara kegagalan sosialisasi mengarah kepada berbagai tingkat asimetri. Jika sosialisasi itu tidak berhasil menginternalisasi, sekurangkurangnya, makna yang paling penting dari suatu mayarakat tertentu, maka masyarakat tersebut menjadi sulit untuk dipelihara sebagai suatu usaha yang layak. Terutama, masyarakat seperti itu tidak akan berada pada posisi untuk membentuk suatu tradisi yang akan menjamin kelestarian masyarakat itu sendiri (Peter L. Berger, 1994: 20). 
Berdasarkan teori pembangunan dunia tersebut maka pemaknaan terhadap jihad merupakan hasil dari eksternalisasi, obyektivasi, dan internalisasi siswa-siswa sebagaianggota masyarakat. Siswa mencurahkan dirinya ke dalam dunia nyata dalam kehidupan sehari-hari (eksternalisasi) dan mendapati pemaknaan jihad dengan cara tertentu di dalam masyarakat (obyektivasi) dan selanjutnya siswa menyerap kembali makna-makna tersebut ke dalam kesadarannya (internalisasi). Makna jihad berlangsung melalui media sosial, yaitu proses yang dipakai mendidik generasi baru untuk hidup sesuai dengan program-program kelembagaan masyarakat dimana siswa berada. Akan tetapi penyerapan makna jihad tidak berlangsung secara deterministik mekanistik melainkan bersifat dialektik dalam waktu lama dimana ia sendiri jadi peserta. Maka, dalam penciptaan pemaknaan jihad, siswa tidak hanya menyerap dari masyarakat tetapi ia juga berfungsi sebagai co-produser penciptaan makna tersebut untuk dirinya dan dunia sosialnya. Pemaknaan jihad oleh siswa, dengan demikian, merupakan hasil dialektika yang secara sosial terbentuk dalam mekanisme yang rumit dan panjang. Pemaknaan yang terbentuk lewat konstruksi sosial kemungkinannya sebangun dengan pengertian teoritis dan normatif berdasar ajaran suci Islam dan tradisi Nabi, tetapi juga kemungkinan sebaliknya.

Demikianlah, maka menurut Jamal Albana, jihad, sejak dahulu sampai sekarang merupakan diskursus yang paling banyak disalahpahami. Bahkan di era modern ini, jihad menjadi wacana yang paling dizalimi, baik oleh kalangan pro maupun kontra syariat, juga dizalimi di dalam dan di luar Islam. Kesalahpahaman ini timbul pertama dan terutama dari pencampuradukan antara jihad dan qital (perang), bahkan pendominasian perang atas jihad dan penyikapan jihad sebagai perang lebih dari yang semestinya (Jamal Albanna, 2005: xx).

Jamal Albana menilai hal itu sebagai kesalahan fatal, karena jihad tidak selalu beriringan dengan perang. Sebaliknya jihad selalu merupakan prinsip pokok sementara qital hanyalah aksidental yang mendesak dilakukan jika memang diperlukan. Sebagaimana sejarah negeri ini Resolusi Jihad digagas oleh $\mathrm{KH}$. Hasyim Asy'ari yang ketika itu menjabat sebagai Rais Akbar Nahdlatul Ulama. Hal ini dimaksudkan untuk melakukan perlawanan terhadap penjajah (Wahid, 2006: 108). Dalam lintasan sejarah dan realitas, Rasul dan sahabatnya telah melakukan jihad di Makkah selama 13 tahun dengan menggunakan sarana-sarana jihad yang mengandung pendekatan hikmah, mauizah hasanah, kesabaran, dan militansi. Dengan jihad seperti itu fase ini telah berhasil menguatkan basis akidah dan keimanan. Penindasan demi penindasan yang dialami selama di Makkah dihadapi dengan jihad damai dan telah merupakan bangku sekolah efektif. Setelah kaum Muslimin hijrah ke Madinah barulah terbuka fase qital terbuka hanya sebagai pembelaan diri dan pembelaan akidah. Inilah menurut Albana kunci rahasia diksi 'agar tidak terjadi fitnah' yang sering disebut dalam ayat-ayat qital (Jamal Albanna, 2005: xxi).

Deskripsi kedua fase tersebut menjelaskan bahwafasejihadbersifattetapdanberkesinambungan, sementara fase kedua (qital) hanyalah fase penyempurna dalam rangka menjamin kebebasan akidah dan menangkal serangan. Karenanya, jika kedua sebab itu tidak ada, maka qital pun tidak diperlukan lagi. Berbeda dengan jihad yang bersifat tetap dan senantiasa diperlukan.

Itulah sebabnya ayat-ayat tentang qital ditempatkan di tengah-tengah ayat lain agar ayatayat tersebut dikendalikan oleh siyaq (konteks) dan menuruti jejak ayat-ayat lain. Yang terpenting lagi, adanya tipologi darurat atas ayat-ayat qital di tengah tipologi imaniyyah-qalbiyyah, juga di tengah dunia kebaikan, perdamaian, dan keadilan yang diaspirasikan ayat-ayat Alquran secara umum. Pemahaman ayat-ayat qital tidak akan terbentuk kecuali jika kita menghadirkan Alquran secara utuh.

Albana melihat kesalahpahaman tentang jihad sebagai qital (perang) terjadi karena kalangan yang membahas diskursus ini lebih sering hanya mencuplik satu atau beberapa ayat, mengucilkannya dari konteksnya, menelanjanginya dari kondisi yang mengiringinya, dan terakhir memutuskan status hukumnya hanya berdasarkan satu atau beberapa ayat tersebut. Kesalahpahaman juga terjadi ketika pemahaman qital itu sendiri yang telah melampaui otoritas tujuan awalnya sebagai usaha menangkis serangan dan menolak fitnah (kekacauan) menjadi lebih luas lagi sebagai media penyebaran akidah. Islamisasi dunia dan usaha penyelamatannya dari jahiliyah modern sekaligus pengenalan hukum Tuhan. Ini merupakan perkembangan genting yang akan membuka pintu pelecehan terhadap kebebasan berakidah bagi pihak lain dan rentan menyeret kita pada dimensi ekstrimisme yang lebih jauh lagi.

Di dalam Alquran terdapat alternatif-alternatif yang luas, lapang dan beragam, sehingga Alquran mampu eksis dan berkomunikasi dengan beragam perkembangan, juga beragam pemahaman. Setiap 
ayat memiliki kedudukan, munasabah, dan asbab (al-nuzul) sendiri-sendiri. Yang terpenting, setiap orang harus mengambil setiap ayat dari konteksnya, juga jangan sampai ada yang fanatis dengan kesimpulan akhir yang didapatkannya, atau sampai berasumsi bahwa hanya pendapatnyalah yang benar sementara yang lain salah. Harus ia katakan: ini adalah pemahamanku dan bagi kalian pemahaman kalian sendiri. Sebab Alquran adalah kitab untuk semua, juga menangani kondisi-kondisi yang berbeda-beda dan terus berubah-ubah.

Jamal Albana memandang bahwa Islam memiliki tipologi jihadisme dan tipologi ini lebih lanjut mengimplementasikan keharusan seorang Muslim untuk ber-suluk khusus dan memegang teguh nilai-nilai jihad dalam Islam, baik secara aktif maupun pasif. Suluk (laku) dan nilai-nilai jihadisme ini merupakan arahan-arahan dan kewajibankewajiban yang termuat dalam Alquran al-Karim dan termanifestasi dalam laku, siasat, dan gerak Rasul (Jamal Albanna, 2005: 25). Medan jihad menurut Jamal Albana begitu luas, (1) Alquran itu sendiri, (2) kesabaran dan militansi dalam menghadapi ketertindasan, (3) Hikmah dan Maw'izah Hasanah dalam mengenalkan dakwah (4) infak, (5) Amar makruf, nahi munkar, (6) pemutihan (al-Muqassah), kebaikan akan menghapus keburukan, dan (7) hijrah sebagai suaka terakhir tatkala kondisi sudah paceklik.

Jihad itu sendiri menurut El-Fadl, merupakan prinsip utama dalam teologi Islam, yang pada dasarnya berarti berusaha sekuat tenaga. Dalam banyak cara, jihad bermakna etos kerja secara spritual dan material. Kasih sayang, pengetahuan, kesehatan, kecantikan, kebenaran, dan keadilan tidak mungkin terwujud tanpa jihad - yakni tanpa kerja keras dan keuletan. Karena itu, membersihkan diri dari kesombongan, menuntut ilmu, mengobati orang sakit, memberi makan orang miskin, dan berpihak kepada kebenaran dan keadilan, meski pun dengan segala resiko pribadi, semuanya merupakan bentuk-bentuk jihad (El Fadl, 2007: 221).

Jihad menjadi simbol sangat kuat bagi keuletan kerja keras, dan kesuksesan dalam sejarah Islam. Tetapi Alquran tidak menggunakan konsep jihad untuk pengertian perang atau pertempuran; tetapi menggunakan istilah qital. Sementara Alquran menyerukan jihad tanpa persyaratan dan tak terbatas, tidak demikian halnya dengan qital. Jihad merupakan suatu yang baik pada dirinya, tetapi qital tidak. Jihad merupakan sesuatu yang baik karena ia sama dengan etika kerja dalam
Protestan: kerja keras untuk jalan kebaikan. Qital, sebaliknya digunakan dalam Alquran dalam makna yang terbatas dan bersyarat (El-Fadl, 2007: 223).

Kuatnya bias pemaknaan jihad bagi siswa bukan saja bersumber dari cara pandang masyarakat tentang jihad sebagai qital yang sudah mengakar, tetapi juga tidak terlepas dari peran sekolah yang kurang memberikan ruang yang cukup bagi penanaman nilai-nilai agama yang sangat penting tersebut lewat palajaran agama. Siswa pun terbawa arus cara pandang yang kurang serasi dengan pembangunan di bidang agama di Negara Kesatuan Republik Indonesia ini.

Belum berhasilnya mata pelajaran pendidikan agama di sekolah tidaklah berarti harus membuangnya. Bangsa Indonesia telah mengambil sikap bahwa penyelenggaraan pendidikan agama di sekolah merupakan amanat Undang-undang. Negara sudah mengaturnya untuk menjamin pelaksanaan Pasal 29 UUD 1945. Bahkan sejak tahun 1966, setiap sekolah sudah diwajibkan untuk menyelenggarakan pendidikan agama.

Dalam kaitan inilah, penyempurnaan sistem pendidikan agama, terutama dalam orientasi dan penekanan aspek kompetensi yang harus diajarkan menjadi hal yang sangat penting. Materi pendidikan agama, harus diorientasikan kepada penguasaan, pemahaman, peghayatan dan pengamalan nilai dan norma ajaran agama secara komprehensif sehingga kelak mampu membentuk kepribadian yang utuh. Pendidikan agama harus disajikan dengan pendekatan yang tepat sesuai idiologi pembangunan yang telah dirumuskan Pemerintah dan tuntutan pembentukan kepribadian peserta didik sesuai perkembangan tantangan zamannya. Kesalahan pendekatan pendidikan agama, ternyata tidak hanya menyebabkan "prestasi" sekolah yang rendah, namun dapat menyebabkan pula terbentuknya prilaku yang tidak kita harapkan.

Dalam kaitannya dengan strategi pendidikan agama, paling tidak, terdapat tiga pendekatan yang dapat dipertimbangkan. Pertama, pendekatan doktrinal (doctrinaire/ecclesiastical approach). Pendekatan ini cenderung lebih mengajarkan (mentransfer) nilai dan norma ajaran agamanya sendiri. Atas keyakinannya terhadap kebenaran absolut agama sendiri, pendekatan ini "mengindoktrinasi" bahwa hanya ajaran agama yang dipeluknya itulah agama yang benar. Agama yang dipeluk orang lain adalah salah. Pendidikan/ pengajaran agama dengan pendekatan ini dapat menumbuhkan dan menyemai fanatisme 
beragama, yang secara sosiopolitik sangat berbahaya bagi keutuhan bangsa dalam bingkai Negara Kesatuan Republik Indonesia. Pendidikan agama berpendekatan doktrinal, saya kira kurang atau tidak tepat bagi bangsa kita yang majemuk dalam berbagai aspeknya.

Kedua, pendekatan studi ilmu sosial (socialstudies approach). Pendekatan ini mempraktikan pendidikan agama dengan pendekatan ilmu sosial. Menurut pendekatan ini, pendidikan agama adalah bagian dari ilmu sosial. Pendidikan agama diajarkan seperti mengajarkan ilmu-ilmu lain yang diorientasikan memberikan pemahaman tentang konsep norma dan nilai agama serta fungsinya dalam tatanan kehidupan masyarakat. Akibatnya, adalah jelas, bahwa siswa hanya menguasai "agama" sebagai ilmu, bukan agama sebagai nilai dan norma yang harus dihayati dan diamalkan dalam kehidupan nyata. Pendekatan ini, secara epistemologis, memang efektif karena mendorong pada penguasaan historisitas, konsep, teori, dan metodologi agama dengan baik. Namun, secara aksiologis, pendekatan ini tidak mampu menghasilkan individu (siswa) yang termotivasi secara kuat untuk menghayati, membatinkan (menginternalisasi) dan mengamalkan ajaran yang telah difahami, dikuasai atau dimilikinya. Dengan demikian, pengajaran pendidikan agama dengan pendekatan ilmu-ilmu social, khususnya pada jenjang pendidikan dasar dan menengah, belumlah tepat.

Ketiga, pendekatan perencanaan sosial (social planning approach). Dalam konteks penyelenggaraan pendidikan agama di negeri kita, saya kira pendekatan perencanaan sosial terakhir inilah yang dapat dianggap "paling tepat" untuk diterapkan. Pendekatan ini diorientasikan pada pemenuhan kebutuhan nyata masyarakat dalam rangka penataan kehidupan masyarakat yang lebih baik di masa depan.

Penulis sependapat dengan Mudzhar ketika mengatakan, bahwa bangsa Indonesia, dengan segenap ciri kemajemukannya, tampak cocok mengembangkan pendekatan perencanaan sosial dalam merealisasikan kebijakan penyelenggaraan pendidikan agama. Diharapkan, penerapan pendekatan ini, dapat mendorong siswa (peserta didik) untuk meresapi, menghayati, dan mengamalkan ajaran/materi agama yang diterimanya. Selain itu, pendekatan ini diharapkan dapat mengembangkan nilai-nilai multikultural, seperti menghormati, menghargai, dan toleran dengan pemeluk dan ajaran agama lain (Mudzhar, 2008).

Eksternalisasi, obyektivasi, dan internalisasi nilai-nilai di sekolah memerlukan desain tersendiri, sehingga sekolah merupakan bukan saja merupakan sumber belajar kebaikan bagi anak-anak didik, tetapi juga pusat keunggulan budaya di dalam masyarakat.

\section{PENUTUP}

Pemaknaan siswa tentang jihad pada daerah kasus didominasi oleh pandangan yang sempit dan lebih mengarah kepada pengertian qital. Hal itu dipahami dari penggunanaan term-term makna jihad sebagai perjuangan, pengorbanan, perang, mati syahid dan pembelaan agama (Islam). Hal ini berbeda dengan prinsip jihad sebagaimana dipahami dari Alquran dan tradisi Nabi.

Tidak ada korelasi yang signifikan antara pemahaman jihad dengan sumber-sumber belajar siswa, termasuk sekolah. Hal ini dapat dipahami sebagai lemahnya peran sekolah dalam memberi pemahaman tentang ajaran Islam yang amat sentral tersebut. Pemahaman tentang jihad, dengan demikian, lebih ditentukan oleh konstruksi sosial.

Meski memiliki pandangan yang puritan tentang jihad, siswa ternyata menolak penyelesaian masalah dengan menggunakan kekerasan atas nama agama. Dengan kata lain, generasi muda Islam tersebut menolak radikalisme agama. Hal ini membawa peluang besar bagi internalisasi pemahaman jihad yang lebih inklusif dan moderat lewat pendidikan agama di sekolah.

\section{UCAPAN TERIMA KASIH}

Terima kasih penulis ucapkan kepada seluruh responden yang telah berkonstribusi dalam penelitian baik responden di Kota Ternate maupun di Kota Makassar. Dan terima kasih pula kepada tim redaksi jurnal Al-Qalam atas termuatnya tulisan ini.

\section{DAFTAR PUSTAKA}

Albana, Jamal. 2005. Revolusi Sosial Islam, Dekonstruksi Jihad dalam Islam. Yogyakarta: Pilar Media.

Berger, Peter L. 1994. Langit Suci, Agama sebagai Realitas Sosial. Jakarta: LP3ES.

Departemen Pendidikan Nasional. 2002. Kamus Besar Bahasa Indonesia. Jakarta: Balai Pustaka.

Depdiknas, 2003. Kurikulum 2004 Standar Kompetensi Pendidikan Agama Islam Sekolah Menengah Atas dan Madrasah Aliyah. Jakarta: Pusat Kurikulum Balitbang Depdiknas.

El Fadl, Khaled Abou. 2005. The Great Theft, Wrestling Islam From The Extremists. USA: Harper Collins.

Harian Tempo, tanggal 10 November 2008. 
Hoed, Benny H. 2008. Semiotik dan Dinamika Sosial Budaya. Jakarta: Fakultas Ilmu Pengetahuan Budaya UI Depok.

Irawan, Deni. 2014. "Kontroversi Makna dan Konsep Jihad dalam Alquran tentang Menciptakan Perdamaian" dalam Jurnal Religi, Vol.X No.1 Januari 2014.

Langgulung, Hasan. 2003. Azas-azas Pendidikan Islam. Cet.V. Jakarta: Pustaka Al Husna.

Mudzhar, Atho. 2008. Sambutan Kepala Badan Litbang dan Diklat RI. Disampaikan Pada Pembukaan Workshop Penyelenggaraan Pendidikan Agama Kristen di Sekolah, Tanggal 26 Mei 2008, di
STAKN Tana Toraja Sulawesi Selatan.

Nahrawi, Muhammad Nahar. 2009. "Perkembangan Pemaknaan Jihad dalam Islam" dalam Jurnal Harmoni. Volume XIII No.32 Oktober-Desember 2009.

Nst, Agus Salim. "Jihad dalam Perspektif Hukum Islam" dalam Jurnal Ushuluddin. Vol.XX No.2 Juli 2013.

Nur, Ma’mun Efendi. 2010. "Hukum Jihad dan Terorisme: Perspektif Al-Qur'an" dalam Jurnal Maslahah. Vol.1 No.1 Juli 2010.

Wahid, Abdurrahman. 2006. Islamku Islam Anda Islam Kita, Agama Masyarakat Negara Demokrasi. Jakarta: The Wahid Istitute. 